\title{
The Stone Age Archaeology of West Africa
}

\author{
Eleanor Scerri
}

\section{Summary}

In the early $21^{\text {st }}$ century, understanding of the Stone Age past of West Africa has increasingly transcended its colonial legacy to become central to research on human origins. Part of this process has included shedding the methodologies and nomenclatures of narrative approaches to focus on more quantified, scientific descriptions of artefact variability and context. Together with a growing number of chronometric age estimates and environmental information, understanding of the West African Stone Age is contributing evolutionary and demographic insights relevant to the entire continent.

Undated Acheulean artefacts are abundant across the region, attesting to the presence of archaic Homo. The emerging chronometric record of the Middle Stone Age (MSA) indicates that core and flake technologies have been present in West Africa since at least the Middle Pleistocene ( 780-126 thousand years ago or ka), and that they persisted until the Terminal Pleistocene/Holocene boundary $(\sim 12 \mathrm{ka})$ - the youngest examples of such technology anywhere in Africa. The presence of MSA populations in forests remains an open question, however technological differences may correlate with various ecological zones. Later Stone Age (LSA) populations evidence significant technological diversification, including both microlithic and macrolithic traditions. The limited biological evidence also demonstrates that at least some of these populations manifested a unique mixture of modern and archaic morphological features, drawing West Africa into debates about possible late admixture events 
between late surviving archaic populations and Homo sapiens. As in other regions of Africa, it is possible that population movements throughout the Stone Age were influenced by ecological bridges and barriers. West Africa evidences a number of refugia and ecological bottlenecks which may have played such a role in human prehistory in the region. By the end of the Stone Age, West African groups became increasingly sedentary, engaging in the construction of durable monuments and intensifying wild food exploitation.

Keywords: Stone Age, West Africa, Human Evolution, Prehistory, Archaeology

\section{West Africa: Geography and Environment}

West Africa is defined by the United Nations as consisting of 18 countries: Benin, Burkina Faso, Cape Verde, Gambia, Ghana, Guinea, Guinea-Bissau, The Ivory Coast, Liberia, Mali, Mauritania, Niger, Nigeria, Saint Helena, Senegal, Sierra Leone, São Tomé and Príncipe and Togo. Together, these countries form about $18 \%$ of the African continent.

This region consists of seven vegetation biomes: (i) Deserts and Xeric Shrublands, (ii) Tropical and Subtropical Dry Broadleaf Forests, (iv) Tropical and Subtropical Broadlead Forests, (v) Flooded Grasslands and Savannahs, (vi) Montane Grasslands and Shrublands and (vii) Mangroves). ${ }^{1}$ In practice, these biomes are represented by highly diverse regions of open savannah grading into closed canopy forest. The Western Sudanian savannahs consist of large trees and long 'elephant grass' (Hyparrhenia). In the wetter regions, the savannahs are dominated by African oak 
(Afzelia africana), wild syringa (Burkea africana), bushwillows (Combretum spp) and large trees of the Terminalia genus. These grade to Sudanian Isoberlinia woodland in the south. In the more arid, northern regions, the savannahs are more open and dominated by medium sized trees such as acacias, thorn trees (Balanites aegyptiaca, Ziziphus mucronata), African myrrh (Commiphora africana), African mesquite (Prosopis africana), Tamarinds (Tamarindus indica) and various shrubs (Combretum glutinosum $).{ }^{2}$ Regions of rainforest consist of their mosaic woodland edges grading into closed-canopy semi-evergreen, lowland evergreen, montane, subalpine, heath, and swamp rainforests, each of which has different structural and floral characteristics. ${ }^{3}$

Both savannah and forest regions are strongly affected by small changes in the West African Monsoon, and the intensity or duration of the dry season, can cause largescale changes in vegetative cover. ${ }^{4-5}$ Currently, the strongly seasonal annual rainfall is as high as $1000 \mathrm{~mm}$ in the southern regions of West African savannahs, but declines in the north, with only $600 \mathrm{~mm}$ on the border with the Sahelian Acacia Savanna ecoregion. Rainfall reaches up to $3000 \mathrm{~mm}$ in regions of rainforest. However, strong evidence of past rainforest retreat into refugia interspersed by open savannah and even desert in the north is today reflected in the current distribution of vegetation and faunal subspecies. ${ }^{6-7}$

\section{Construction of the Archaeological Record}

\section{Terminology}

West Africa is here understood as consisting of the 18 countries listed above, but does not include the south-western Sahara. This is because the Sahara appears to be a 
discrete entity with respect to the Stone Age past, which can be differentiated from the Western Sahel and tropical West Africa on both archaeological and palaeoenvironmental grounds. ${ }^{8-10}$ Therefore, only West Africa's sub-Saharan regions will be considered here. Although not part of the modern day West African region, Cameroon's Stone Age archaeology is also included as the topographic and ecological gateway into West Africa.

Discussion of West Africa's archaeological material utilises the terms proposed in the African Archaeological Congress by Goodwin and Van Riet Lowe in 1929. The terms 'Earlier', 'Middle' and 'Later' Stone Age intended to differentiate African prehistory from that of the 'Lower', 'Middle' and 'Upper' Palaeolithic of Europe, which appeared to be much older and more sophisticated at the time. The use of the Africanist terms was officially abandoned in 1965 to revise and standardize the terminology of African prehistory. ${ }^{11}$ However, a terminological divide between Saharan and sub-Saharan remains in the use of European and Africanist terms, respectively. This is the case despite the recognition of geographically overlapping material culture similarities (see e.g., Scerri et al. ${ }^{12}$ ).

The use of the terms Earlier Stone Age (ESA), Middle Stone Age (MSA) and Later Stone Age (LSA) are used here for the sake of convention and simplicity (see Groucutt and Blinkhorn ${ }^{13}$ for discussion). Furthermore, while the ESA and MSA can sometimes be seen as broadly analogous to the Eurasian Lower and Middle Palaeolithic, differences between the LSA and the Upper Palaeolithic are such that the two terms are often used in Africa to denote separate cultural referents. Although again problematic, for the sake of this review the LSA is taken to end as a cultural 
phase with the emergence of semi-sedentary societies engaging in the beginning of food production.

\section{State of Knowledge: Rapid Overview}

There has been a long history of research in West Africa. As in other regions of Africa and the world, the history of research has greatly influenced the construction of the archaeological record and the character of research themes and narratives.

Currently, the record is primarily constructed using artefact typologies and named industries. These typologies are broadly used to address research themes concerning human evolution in the Pleistocene and the emergence of politically complex, food producing societies in the early Holocene. However, the lithic industries underpinning much of the archaeological sequence often come from undated sites in disturbed or surface contexts. This is particularly the case for the earlier, Pleistocene, part of the record (see below).

Currently, the presence of an Oldowan Earlier Stone Age (ESA) in West Africa remains unclear. Acheulean ESA artefacts are well documented across West Africa, although they may be absent from the most tropical regions. None are currently dated. There are few dated Middle Stone Age (MSA) sites, but they range from the Middle Pleistocene in northern, open Sahelian zones to the Late Pleistocene in both northern and southern zones of West Africa. A surprisingly late persistence of the MSA into the Terminal Pleistocene/Holocene boundary is also documented. The environmental context of many of these sites is not yet well understood. At present there is no concrete evidence that MSA populations lived in closed canopy forests. Many questions also remain concerning the taxonomic identity of MSA stone tool 
producers, particularly as late hybridization processes between archaic populations and Homo sapiens is increasingly considered possible. The persistence of fossil, and possibly genetic diversity into the Terminal Pleistocene and early Holocene has resulted in the recognition that until recently, West Africa was more culturally and biologically complex than has been typically considered.

Such late persisting biological and cultural complexity has also fed into narratives of later prehistory, which attempt to understand the mosaic-like emergence and character of the Later Stone Age (LSA). This emergence, its relationship with the population expansions and the social and cultural changes associated with the emergence of food producing societies, is a major topic of research. Limited chronometric age estimates suggest that the LSA begins later in West Africa than in Central and Central-Western Africa. In West Africa, the LSA commences at least by Marine Isotope Stage (MIS) 2, overlapping with final MSA industries. ${ }^{14-15} \mathrm{By} \sim 11 \mathrm{ka}$, scattered groups of LSAproducing people were established across West Africa, and are often in the literature connected with processes of population expansion into the Sahara (e.g., MacDonald $\left.{ }^{16}\right)$. However, the limited fossil data does not support this hypothesis. ${ }^{17}$ What the record does show is that aceramic and ceramic LSA assemblages in West Africa overlap chronologically, and that changing densities of microlithic industries from the coast to the north are geographically structured. These features may represent social networks or some form of cultural diffusion allied to changing ecological conditions.

Microlithic industries with ceramics became common by the Mid-Holocene, coupled with an apparent intensification of wild food exploitation. ${ }^{18}$ Between $\sim 4-3.5 \mathrm{ka}$, these 
societies gradually transformed into food producers, possibly through contact with northern pastoralists and agriculturalists, as the environment became more arid. ${ }^{19}$ However, hunter-gatherers may have survived in the more forested parts of West Africa until much later, attesting to the strength of ecological boundaries in this region.

This record and its palaeoenvironmental context are considered in detail below, together with its construction and political and cultural milieu. Major questions emerging from the record are evaluated in the conclusion as an outcome of the available data. Although interpretation of the record is still strongly affected by its research history, new research programmes are starting to reconstruct the record from more neutral, scientific perspectives through chronometric dating programmes and environmental reconstruction. While this research on the West African Stone Age is still in its very early stages, existing research points to a rich and varied record, which is beginning to contribute to pan-African debates on human origins ranging well into the Holocene.

\section{History of Research}

Research interest in the West African Stone Age has enjoyed a number of peaks and troughs. In the first half of the $20^{\text {th }}$ century, research interest was equivalent to other regions of Africa. However, with growing interest in 'Out of Africa' routes used by early Homo sapiens and wide consensus for the East African origins of our species, West Africa was increasingly perceived as a backwater to the main stage of human evolution. In the early $21^{\text {st }}$ century, however, there is a growing recognition that all of Africa played a role in recent human origins, thanks to advances in genetic research 
and the discovery that the earliest fossils of our species are located in northwest Africa. ${ }^{20}$ These shifts in understanding are leading to a renewed interest in the West African Stone Age.

Colonial Era (1780s-1920s)

The history of research in West Africa has roots in French and British colonialism. French West Africa consisted of most of the countries that today form West Africa, with the addition of Algeria. These West African countries included Mauritania, Senegal, French Sudan (now Mali), French Guinea (no Guinea), Ivory Coast, Upper Volta (now Burkina Faso), Dahomey (now Benin) and Niger, and formed a federation whose capital was at Dakar in Senegal. Nigeria, Liberia, Ghana, The Gambia and Sierra Leone formed British West Africa.

Preceded by Portuguese colonisation, the British colonisation movement began in West Africa in the 1780s, while the French movement began almost a century later, during the so-called 'scramble for Africa'. The two movements were fundamentally different in that French colonial policy was to centralize and assimilate its African territories into a single political and socio-cultural entity. In contrast, Britain administered its West African territories as separate and distinct colonies. ${ }^{21}$ As a result, there was a greater emphasis in comparison and integration in Francophone West Africa, whereas amateur and professional archaeological work in Anglophone West Africa largely occurred in isolation and in ignorance of contemporary research going on elsewhere in the region. 
In French West Africa, the colonial period saw the collection of surface artefacts by various soldiers, merchants, explorers and administrators, who sent their collections to France for study by contemporary authorities that had never set foot in West Africa. ${ }^{22}$ Like the rest of Francophone Africa, these prehistoric finds were therefore set within the sequences developed for the French Palaeolithic, but situated at the peripheries of the European main stage. ${ }^{23}$ Africa was generally perceived as having had no real history of its own, which led to a stronger focus on its prehistory. However, implicit racism characterised this prehistory, like the more recent past, as stagnant and primitive. ${ }^{24-25}$

In British West Africa, prehistoric archaeological research was inadvertently conducted by geologists during their fieldwork, as well as by amateurs. ${ }^{26}$ Reports on prehistoric archaeological occurrences were therefore contained within the records of various geological surveys and finds were largely sent back to the United Kingdom. The geological context of research meant that any archaeological finds were situated within an appreciation of past climatic variation and geomorphological shifts, even if the archaeology itself was only incompletely recorded. This meant that the antiquity of the region's Stone Age past was recognised from the earliest investigations.

In French West Africa, chronological interpretations were strongly affected by the perceived blending of Africa's past and present. Debates centred on the relationship between stone tools and possible racial affiliations, with the assumption that any observed 'advances' were the product of external, non sub-Saharan African, influences. However, unlike the Maghreb region further north, there were no speculations regarding any direct relationships between the West African Stone Age 
and the European Palaeolithic. Instead, the sub-Saharan African past was very clearly linked to its present, fitting well with the concurrent justification of colonialism. Stone Age cultures were perceived as having been influenced by those in North Africa, which were in turn linked to the European peripheries. The first sponsored excavations, which took place in Conakry, Guinea, between 1883 and 1907, attempted to set an early interest in the region for its own sake, framed in terms of understanding African populations and arguing for continuity between past and present. $^{27}$

Transitional Period and Independence (1930s-1970s)

Prior to the 1930s, there were few sponsored excavations and many random collections by colonial officials and visitors - most of which continued to be sent to France. Furthermore, as these finds were mostly recovered from surface localities, they were concentrated in arid regions of high visibility. Few artefact collections or fieldwork investigations took place in forested savannah and tropical regions. ${ }^{28} \mathrm{~A}$ major change to the above practices begun with the creation of the Institut Francais d'Afrique Noire (IFAN) in Dakar in 1938. The creation of this institute provided a centre for artefact curation and research within West Africa itself, rather than France and the creation of the first historical and archaeological museums in West Africa. The creation of these museums also established professional archaeologists in both Dakar and Bamako for the first time. Raymond Mauny was named head of the Archaeology-Prehistory division at IFAN-Dakar, which was formed in 1938. Georges Szumowski was named the director of IFAN-Bamako, which was set up later, in 1951. A branch of IFAN was also set up in the Ivory Coast in 1943, which ultimately became the National Museum of Abidjan in 1972. 
In Dakar, Mauny was prolific, and produced a significant body of research on West African prehistory, including synthetic contributions on the state of knowledge of rock art, ceramic analysis, the origin of copper and metallurgy as well as bone and stone tools. These syntheses were paralleled in Anglophone West Africa by Oliver Davies, who also attempted to present an overview of the non-Francophone regions. ${ }^{29}$ No further studies on a similar scale have yet been produced. ${ }^{30}$ Perhaps Mauny's greatest contribution was the recognition that archaeological research in West Africa was in its infancy, leading to his pushing for a programme of site inventory and stratigraphic excavation, more sophisticated lithic analysis and chronological work. ${ }^{31-}$ 32

In British West Africa, a museum in Ghana at Achimota College was established in 1937, with its own professional archaeologist, Thurstan Shaw. In Nigeria, another professional archaeologist, Bernard Fagg, became an Assistant District Officer within the Nigerian Administrative Service and a Nigerian Antiquities Service was established in 1943. Both Shaw and Fagg were interested in Stone Age archaeology, although both also significantly contributed to the understanding of later periods of West African prehistory and history. Despite his shifting interest towards later time periods, Fagg did contribute to recording the Stone Age record in Nigeria, particularly at its most famous sites, Nok and Zenabi (see Table 1). ${ }^{33}$ Elsewhere, in Legon, Ghana, the archaeology department's appointment of Oliver Davies in 1952 resulted in a new drive to locate fossil hominins in West Africa along with ESA and MSA artefacts. Although such fossils were never found, Davies logged the locations of hundreds of prehistoric sites of various types across Ghana. ${ }^{34}$ 
Following Mauny's retirement from IFAN in the 1960s, academic and geopolitical shifts, including the collapse of French West Africa, led to the demand and need for programmes focusing on African history in both secondary schools and Universities. ${ }^{35}$ This led to conflicts between native African specialists such as Cheikh Anta Diop, and European Africanists regarding the role of African people in their own history and prehistory. ${ }^{36-39}$ This was the first time an African challenged European concepts in favour of cultural diffusionism as an explanation for African advances. Such important challenges during the first decades of independence resulted in an increase in excavations across West Africa, with a major focus on exploring the origins of West African civilisations and towns. By the 1970s, university-based History departments were created in Togo, Benin, Niger and Burkina Faso. By 1981, the IFAN had renamed itself as the Institut Fondamental d'Afrique Noire and became fully Africanized. In the Ivory Coast, the National Museum of Abidjan became the Musée des Civilisations de Côte d'Ivoire in 1994, following an initiative by Professor Georges Niangoran Bouah, a leading figure in the decolonisation of academia in the country.

Anglophone West Africa paralleled these developments. With independence, new governments focused on indigenous archaeology and national heritage. Museum networks opened across Nigeria, a national museum opened in Ghana, and University departments were established in both countries. However, in Liberia, the Gambia and Sierra Leone, development of an African archaeological community has been limited.

Despite these advances, Stone Age archaeology lagged behind in a general drive to understand the indigenous origins of West African civilisations. Other factors stalling 
development include the difficulty of locating sites and associated taphonomic problems. Compared to East Africa, for example, which is a zone of tectonic uplift, much of West Africa is low lying and often flooded during the rainy season, contributing to significant sediment accumulation. Methodological issues also compounded taphonomic ones. Bordesian systematics never penetrated West Africa. ${ }^{40}$ Such systematics revolutionised studies in Europe by replacing an approach based on identifying fossiles directeurs with studies of the relative frequencies of tool types in assemblages. In Francophone West Africa, Mauny’s successor, Henri-Jean Hugot distrusted statistically derived stone tool types, affecting the validity of comparative studies and named stone tool industries. ${ }^{41}$ While systematic, scientific investigation with chronological and environmental dimensions became established for later prehistory, by and large, the perception of West Africa as a cultural backwater throughout most of earlier prehistory has continued to the present day. In Anglophone West Africa, focus also remained fixed on later prehistoric, proto-historic and historic periods, leading to a comparable state of research with regards to the Stone Age.

\section{Research in the late $20^{\text {th }}$ and early $21^{\text {st }}$ centuries}

By the late 20th century, the Stone Age record in West Africa was still largely known from surface sites, usually from disturbed contexts. Most of these sites were discovered through mining activities in West Africa, and often found out of stratigraphic context. ${ }^{42-43}$ This has limited inference to broad typological considerations, which lack chronological control.

While typology is a useful heuristic, without further technological and contextual detail it can lead to an overformalisation which obfuscates variability. In West Africa, 
these considerations have resulted in three typological categories: [1] those typically implemented within the methodological and interpretative frameworks developed for the Palaeolithic of France; [2] those associated with Equatorial industries (e.g., Sangoan, Lupemban); [3] a somewhat uncontrolled mixture of spatial and temporal variation categorised by ecozone. For example, sites in the arid, northern regions of West Africa tend to be linked to North Africa (e.g. 'Middle Palaeolithic'), while terms typically associated with poorly understood Equatorial industries (e.g., Sangoan, Lupemban) have been used to describe stone tools from tropical West Africa.

All these problematic typological considerations have led to numerous new industrial assignations that lack chronological or stratigraphic assessment. For example, the high typological diversity of the 'Tiemassassanian' in Senegal has led to debates over whether the 'industry' can be classified as Middle or Upper Palaeolithic (or MSA and LSA), Mesolithic or Neolithic, which still continue into the $21^{\text {st }}$ century. ${ }^{44-48}$ The 'Mousteroid' category, on the other hand, was intended to differentiate typical MSA assemblages from similar assemblages in North Africa because a 'Middle Palaeolithic' was not thought to extend south of the Sahara.

The record is further problematized by spatial biases. Both amateur and scientific archaeological work has largely taken place in the open and more arid regions of northern West Africa, particularly where public works or mining activities occurred. Knowledge remains extremely limited in the forested areas of the south, in which visibility is limited and working conditions difficult. Liberia was briefly investigated in the late 1960s, with a more comprehensive survey carried out in the 1970s by a team from Boston University. ${ }^{49-51}$ Middle and Later Stone Age occupations were 
identified. The southern regions of Cameroon, the gateway to West Africa was also investigated by the Tokyo Metropolitan University Geographical Expedition to Cameroon, which identified numerous Stone Age sites described as Sangoan and Lupemban (see Allsworth Jones, $1986^{52}$ for a synthesis). Similar sites have also been reported in Nigeria, the Ivory Coast and Ghana. ${ }^{53-55}$ istepipHowever, the use of these terms in a West African context continues to be disputed on the grounds that assemblages assigned to these industries in West Africa lack the full suite of characteristics used to define them elsewhere. ${ }^{56}$

More recent, chronometrically dated sites are revealing a record that does not necessarily have close parallels with other regions of Africa (see below). As a result, previous statements about the West African record are all open to re-evaluation. The challenges of constructing a record from so little has meant that it is not always clear which cultural designation to give the few dated stone tool assemblages from sites spanning MIS 5 to the Terminal Pleistocene. Currently, it seems clear that the West African record is at least culturally ancient, with an undated ESA and an apparently late MSA that overlaps with LSA assemblages in the Terminal Pleistocene (see below). Ultimately, only significant new fieldwork will be able to shed light on the West African sequence and its character, particularly in the different ecological zones. This is because the significant differences between the northerly and southerly ecological areas of West Africa problematize any broad-scale extrapolations made from single sites to the entire region. Furthermore, the ecological complexity of West Africa means that broad divisions between 'open/arid' and 'humid/forested' are themselves overly crude. 


\section{Description of the West African Stone Age record and its context}

\section{Major questions}

The state of West African Stone Age research today is rapidly improving. There is a recognition that many past inferences are problematic, an outcome of research biases and inconsistent analyses affected by past socio-historic and political milieus.

Research is now instead concerned with situating Stone Age archaeological evidence within its geomorphological, chronological and environmental context in order to begin to construct models of the Stone Age past based on a robust body of data. As noted above, much of this new research is in its early stages. However, it is already contributing to constructing a new record for West Africa, which emphasises uniqueness, antiquity and complexity.

The major questions relating to the record concern (1) the earliest human occupation of closed-canopy forests (see e.g. Roberts and Petraglia ${ }^{57}$ ), (2) the general antiquity of the human presence in West Africa, (3) the taxonomic identity of the hominins responsible for the ESA and MSA, (3) the late persistence of archaic biology and 'anachronistic' culture (see e.g., Scerri et al. ${ }^{58}$ ) and (4) the character of the complex transition to the LSA and its associated population expansions. As described in detail below, West Africa's ecology and palaeoecology are increasingly recognised as complex, temporally overlapping in parts and time transgressive in others. The ESA remains the most poorly understood of all cultural phases, while chronometric dates are starting to become available for MSA and LSA sites. The end of the Stone Age in West Africa is difficult to delineate, but it is generally thought to end with the rise of advanced technical traits and increased sedentism immediately preceding the discovery and use of metals. ${ }^{59}$ 


\section{Palaeoclimate}

Palaeoclimate research in West Africa is still in its infancy. Offshore sediment records from the Gulf of Guinea and the tropical Atlantic indicate that patterns of forest expansion occurred repeatedly, coinciding with interglacial periods in the latter half of the Quaternary. ${ }^{59-61}$ A recently recovered 500,000 year long pollen record from Lake Bosumtwi in Ghana provides important information on the responses of vegetation to such global climate shifts. ${ }^{62}$ The records from Lake Bosumtwi reveal dynamic vegetation changes indicative of oscillating savannah and forest conditions, which were both drier and wetter than current conditions. Records reveal that past savannahs were dominated by grass and pollen associated with sedges (Cyperaceae) and flowering plants (Chenopodiaceae-Amaranthaceae), including the carnation family (Caryophyllaceae). Forest pollen was typically more diverse, with key taxa occurring in multiple forest zones including flowering plants from the fig family (Moraceae, e.g. hackberries) and tropical trees (Macaranga). Critically, the records show that savannahs appear to have dominated over the last $\sim 500 \mathrm{ka}$ in lowland tropical West Africa. However, six periods of forest expansion are evident and likely corresponding to global interglacial periods. Comparisons of these periods of forest expansion suggest that the driest interglacial corresponds to MIS 7, and the wettest with the Holocene Wet Phase.

Within faunal communities, these repeated periods of ecological fragmentation provided critical mechanisms for speciation. As a result, West Africa is one of the most biodiverse regions of the continent, with endemic species and subspecies in both savannah and forested zones (e.g., pygmy hippos, Jentink's Duiker, the Giant Eland, 
the African buffalo, the Common Potto and the Diana Monkey). The effect of ecological fragmentation and environmental shifts on Pleistocene human populations in West Africa is much less well understood, primarily because the environmental context of human habitation is poorly known. It seems likely that human populations lived in regions of savannah, in part because this is established elsewhere in Africa, and in part because numerous stone tool assemblages have been found in the present day Sahelian regions, which were never areas of rainforest. However, numerous studies indicate that rainforest regions could have been inhabited by Pleistocene humans [see e.g. Roberts and Petraglia ${ }^{63}$ ]. If this was the case, human populations adapted to closed canopy environments are likely to have been separate from others inhabiting the savannah zones, a possibility that may be reflected in patterns of stone tool diversity.

\section{Chronology}

Chronological control of the West African Stone Age archaeological record is currently extremely limited. The robusticity of chronometric dates and the certainty of exactly what is being dated is also somewhat varied, with the most recently dated sites being the more reliable. See Fig. 1 for locations of key sites.

\section{Table 1 here}

\section{Material Culture}

Earlier Stone Age (ESA)

Very little is known about the ESA in West Africa, in large part thanks to differences in underlying geology. For example, there is no faulting to expose rapid Late 
Tertiary/Early Quaternary sedimentation, as seen in East Africa. Different topography, temperature and rainfall patters in West Africa also result in poorer preservation conditions compared to other regions of the continent. Pliocene and Pleistocene sediments are also rare thanks to regular flooding events leading to extensive sediment deposition in what is a generally low-lying region of Africa.

The earliest reported ESA in West Africa relate to a purported Oldowan presence that remain controversial since pebble 'choppers' can be found in West African assemblages of any period (see below and McIntosh and McIntosh ${ }^{64}$ ). While an Oldowan presence in West Africa is certainly possible, there is currently no clear evidence to support it.

In contrast, the IFAN contains numerous Acheulean-like artefacts from all over West Africa (Fig. 2). However, there are currently no direct chronometric age estimates from primary context in association with such artefacts from anywhere in the region. In Senegal, Acheulean-like artefacts have been reported in the Falémé River Valley in undated and probably reworked contexts. At Djita, in the Lower Falémé River Valley an industry described as Acheulean was excavated from layers 2 and 3 at the site (Fig. 2). ${ }^{65}$ The assemblage consisted of flakes, pebble tools, choppers, handaxes, side scrapers, notches, discoidal cores and a single Levallois core. The somewhat mixed technological character of the assemblage led the excavators to describe it as a 'Final Acheulean', with a proposed date of 130ka based on problematic correlations between marine cores and local terrace systems. ${ }^{66}$ Similar assemblages in the same region were reported at Kidira and Sansandé (Fig. 2). Industries described as having an 'archaic appearance' have also been documented at Karé. ${ }^{67-69}$ At the site of Berges d'Alinguel, 
a possible ESA assemblage featuring large flakes, pebble tools and handaxes in a reworked context has a terminus ante quem date of $\sim 88 \mathrm{ka}^{70}$

\section{Fig. 1 here}

Elsewhere, Acheulean material has been reported from generally upland regions with sediment preservation. Acheulean assemblages have been reported in southeastern Ghana and central Togo along the Atakora highlands and the Jos Plateau in Nigeria, where bifaces were discovered as a result of tin mining in alluvial deposits. ${ }^{71-72}$ At Ugwuele in eastern Nigeria, an Acheulian quarry site, large quantities of processed brittle dolerite, including broken and unfinished handaxes, have been reported. ${ }^{73}$ No Acheulean has yet been reported in the far south and most tropical regions of West Africa, such as Sierra Leone, Liberia and the lowlands of the Ivory Coast. Such a lack of reported finds may reflect the absence of focused fieldwork in these regions and the difficulties of field conditions, rather than a true gap in the record.

In terms of chronology, previous radiocarbon estimates are unlikely to be reliable and at best represent minimum ages. The earliest optically stimulated luminescence (OSL) dated occupation at the site of Ounjougou in Mali features polyhedrons, sub-spheroids and spheroids in quartzitic sandstone, associated with worked pebbles. A date of $\sim 150 \mathrm{ka}$ in the overlying layer provides a terminus ante quem for this assemblage, which has been described as 'archaic', and, on the basis of typology, possibly up to half a million years old. ${ }^{74}$ No handaxes have been found at the site, although they are present in surface and undated contexts over vast regions of West Africa, from Senegal and southern Mauritania, northern Mali and Nigeria and Burkina Faso. 


\section{Fig. 2 here}

Middle Stone Age (MSA)

MSA assemblages in West Africa (Fig. 3) have typically been identified through typology and categorized using a number of terms with links to other regions, such as 'Sangoan', 'Lupemban', 'Aterian', 'Mousteroid'. Local industrial terms and facies names (e.g. Evolved Palaeolithic, Tiemassassanian) have also been used to describe MSA assemblages from the region. However, with little stratigraphic and chronological control, it is difficult to determine the extent to which the use of these terms is helpful. For example, as iterated above, evidence of the Sangoan and Lupemban in West Africa has been disputed. ${ }^{75}$ It is also worth noting that the assemblages these terms refer to in Central Africa are themselves poorly understood. For these reasons, the variability of MSA assemblages are described here without industrial referents using the available descriptions from reported sites.

The first stratified MSA assemblages in West Africa were recovered from the sites of Asokrochona and Tema West, in Ghana. Both sites are close to the coast on the Accra Plains and with occupations apparently associated with open savannah conditions. Similar assemblages have been reported from Asokrochona and Tema II, the earliest comprising a large percentage of quartz flaking waste, scrapers, knives, notched pieces, picks, bifaces, core axes and choppers, with no prepared core technology. ${ }^{76}$ The assemblages are considered MSA due to the high percentage of flakes, but have been described as 'Sangoan' due to the presence of the heavy-duty elements, such as the picks and choppers. At Asokrochona, the assemblages are estimated to be between $\sim 20-13 \mathrm{ka} .{ }^{77}$ Above this layer are increasing numbers of small tools, which include 
possible Levallois flakes and cores. Both levels have been assigned to the 'Asokrochona Industry'. However, in the absence of more detailed analysis and chronometric dating, the use of such specific terms should be avoided, as they only serve to obfuscate overall lithic variability. Similarly, at Tema II, a 'Sangoan' is estimated to be between $25-20 \mathrm{ka}^{78}$ Overlying assemblages also lack heavy-duty elements and include Levallois cores and reported tanged points, which appear to be distally retouched flakes (see Nyaagard and Talbot ${ }^{79}$ Fig. 6). A younger MSA assemblage was estimated to be between $\sim 12-13 \mathrm{ka}$, but has not been chronometrically dated ${ }^{80}$ Elsewhere in Ghana at the site of Birimi, Levallois flakes and cores, discoidal cores, blades, bifaces, notched pieces, denticulates and retouched flakes and blades were discovered. Thermoluminescence (TL) and OSL dating of sediments associated with the archaeology yielded a date of $\sim 40 \mathrm{ka}^{81}$ It is therefore possible that at least the non-heavy duty assemblages from Asokrochona and Tema II are the same age.

\section{Fig 3 here}

In Senegal, numerous MSA-like sites have been reported, but few have been dated (e.g., Ravisé ${ }^{82}$; Camara ${ }^{83}$; Diop ${ }^{84}$ ). Most sites were reported through major public works or mining activities, leading to a strong element of bias in the distribution of known sites. ${ }^{85}$ Many of these sites were also found out of stratigraphic context. ${ }^{88-99}$ Site concentrations were reported along the coast, around the Dakar region, along the major rivers and in the mining regions of the southeast. Much less in known outside these regions. In the Gambia Valley, assemblages with worked cobbles have been found, at Kedougou, Laminia and Samekouta. ${ }^{100-101}$ In the Niokolo Koba National Park, an assemblage with blades and endscrapers was described. ${ }^{102}$ All these sites currently lack dates. 
More recently dated and excavated sites have demonstrated the presence of an MSA record spanning from MIS 3 to the Holocene (Fig. 3). ${ }^{103-105}$ In the Falémé River Valley, occupations seem to have been densest in MIS 3. ${ }^{106}$ However, in northern Senegal, an extremely young MSA dating to $11.7 \mathrm{ka}$ appears to have been widespread. ${ }^{107}$ The assemblages are characterised by small preferential Levallois cores, core axes, denticulates, points and side and end retouched flakes ('scrapers') made from chert and limestone. This is striking, both because LSA sites have been documented at the same time in the Falémé, and because these sites are the youngest currently known MSA sites in the entire African continent. These data indicate a complex transition to the LSA and the late persistence of 'anachronistic' technology, which may represent population isolation through either cultural boundaries or ecological barriers (e.g., forested areas versus areas of savannah).

In Senegal's western central coastal region, a series of localities along the Tiemassass River has yielded artefacts dubbed the 'Tiemassassanian'. The artefacts have been described as variously Neolithic, Mesolithic and Palaeolithic/Stone Age, but recent detailed analyses suggest that an MSA attribution is the most appropriate. ${ }^{108}$ Assemblages from the site are primarily flake-based and characterised by diverse strategies of raw material exploitation in relation to the morphology and morphometry of the exploited pebbles, including Levallois, discoidal and opportunistic flaking methods. ${ }^{109}$ Tools include various side and end retouched flakes ('scrapers'), notches, denticulates, points, fairly crude bifacial foliates, retouched bladelets and even tanged tools. The latter tool type has long linked the 'Tiemassassanian' to the Aterian. 
However, this hypothesis can only be confirmed by the controlled excavations, which are currently underway at the locality.

In Nigeria, Allsworth-Jones ${ }^{110}$ summarised the state of research, synthesising a number of classic MSA sites from the northern regions. Nok and Zenabi, the most important MSA sites from northern Nigeria, were described as consisting of disccores and blades with prepared platforms. ${ }^{111} 31$ archaeological occurrences described as having a low 'heavy duty' (i.e. large cutting tool) component were also reported by Soper ${ }^{112}$ during his reconnaissance work in northern Nigeria. According to Soper, these archaeological occurrences could be contrasted to the 'Sangoan industry' present further South in that they were dominated by 'disc' and Levallois cores, flakes and blades with facetted platforms. ${ }^{113}$ Subsequent studies of Nok, Zenabi and assemblages from Pingell (Fig. 1) also described an abundance of the Levallois technique. ${ }^{114}$ Two facies for the MSA of Nigeria were proposed. ${ }^{115-116}$ The 'Mai Lumba' facies (Fig. 3) is described as placing a greater emphasis on the Levallois method compared to the 'Zenabi' facies. ${ }^{117}$ It is possible that such differences relate to chronological and/or ecological factors, but in the absence of further contextual data, it is difficult to evaluate the significance of such apparent facies.

In Cameroon, sites are mainly known from the more arid, northerly regions thanks to improved surface visibility. The best studied MSA site is that of Mayo Louti, which features a high number of Levallois cores and flakes. ${ }^{118-119}$ According to AllsworthJones $^{120}$, Mayo Louti, it is very similar to the Mai Lumba assemblages from northern Nigeria (Fig. 3). The Douroumian Formation, which includes the archaeological 
levels from these sites has been dated by radiocarbon to between $\sim 35-25 \mathrm{ka}$, but these dates lack the rigour of more recent chronometric methods and may not be reliable. ${ }^{121}$

In southern Mali, in Dogon country along the Bandiagara escarpment, classic MSA artefacts from a series of river cuts have been reported from the locality of Ounjougou, a complex of sites extending over about $10 \mathrm{~km}^{2}$. The sites within the Ounjougou locality preserve a somewhat disjointed record of occupation, which varied from sporadic to significant over a timeframe largely ranging from 10022ka. ${ }^{122}$ The earliest MSA occupation of the site consists of a single Levallois core with preferential removals described as isolated but in stratigraphic context, was dated by OSL to $\sim 150 \mathrm{ka}$ (MIS 6). ${ }^{123}$

At the site of Kokolo II at Ounjougou, cores and core tools were dated to between 80-60ka and may therefore represent a MSA dating to MIS 5 ( 125-72ka), but only if the earliest end of the dating range is accepted. ${ }^{124}$ Occupations are densest in MIS 3 ( 57-30ka) and MIS 2 ( 29-14ka). Stratigraphic discontinuities and a high degree of technological variation between assemblages is strongly indicative of frequent population turnovers. Blades appear at $\sim 60 \mathrm{ka}$, while discoidal flaking appears between $\sim 55-50 \mathrm{ka} .{ }^{125}$ Levallois, discoidal, laminar and other assemblages (e.g., with bifacial foliates, seemingly archaic assemblages) do not occur in any fixed fashion and do not appear to have any continuity. ${ }^{126}$ As a result, it has been difficult to link the Ounjougou sequence with any single site or technocomplex known from elsewhere in Africa. References to the Aterian at Ounjougou do not stand up to scrutiny as there are no tanged tools known from the site and the reported bifacial foliates do not resemble anything known from North African contexts. 
The site of Bété (Anyama) on the Ivory Coast features an assemblage described as a local variant of Sangoan, containing bifaces and picks. The character of this assemblage is difficult to evaluate as the detailed analysis is in Russian and uses a unique typological system devised by the authors. ${ }^{127}$ The assemblage has a terminus post quem date of $\sim 254 \mathrm{ka}$ (Table 1 ) and is overlain by an assemblage described as more classically 'Middle Palaeolithic'. ${ }^{128}$

On the basis of the few sites with stratigraphic and/or chronological details it seems likely that the MSA of West Africa spanned from at least the Middle Pleistocene to the Terminal Pleistocene/Holocene boundary. The diversity observed between the different MSA assemblages is likely to reflect both chronological and environmental factors - neither of which are currently well understood. The use of various industrial referents does not provide much clarity at present, but it may be the case that the West African MSA can be defined through its own variability, rather than through similarities with other regions. In particular, the MSA in the region seems to persist much later than in other regions of Africa, raising questions about population isolation and even hybridization with late persisting archaic human populations (see below). Technological differences between Sahelian zone, which features classic MSA core and flake technologies and forested zones, which feature heavy duty components, may provide early support for hypotheses of population subdivisions and isolation.

\section{Later Stone Age (LSA)}

The earliest Later Stone Age (LSA) in the region dates from MIS 3, indicating a significant overlap in the region with the MSA. The LSA is marked by a significant 
reduction in tool size in the form of microlithic tools, sometimes appearing in standardised, geometric forms. ${ }^{129}$ At the Shum Laka Rockshelter in northern Cameroon, a microlithic industry on quartz with backed tools was dated in multiple layers to between $\sim 32-11 \mathrm{ka}$ by radiocarbon (Table 1 ). ${ }^{130-131}$ Similarly, an LSA consisting of geometrics, drills and heavy scrapers was dated to $\sim 34 \mathrm{ka}$ at Njuinye in southern Cameroon. ${ }^{132}$.

In the rest of West Africa, the LSA appears to be a little younger and also largely represented by microlithic industries. In Senegal, the LSA in the Falémé River Valley has been dated to MIS 2 at a number of localities (Fig. 4). The earliest, Toumboura 1, dates to $\sim 15 \mathrm{ka}$ (Table 1) and is characterised by backed pieces, including backed microliths, segments and points. ${ }^{133}$ In Nigeria, an assemblage abundant in geometric microliths has been dated to $\sim 12 \mathrm{ka}$ in the basal layers at the Iwo Eleru Rockshelter, which is likely to have been a rainforest during this time, as it is today. ${ }^{134}$ In the Ivory Coast, a non-geometric microlithic assemblage from Bingerville highway has been dated to $\sim 13 \mathrm{ka}$ (Table 1).

Across the region, the character and frequency of aceramic geometric microlith assemblages appears to be varied in West Africa, from site to site, and in same cases, use of the term 'microlith' may be controversial. ${ }^{135}$ Standard microlithic forms are rare, although the use of small flakes $(\sim 2 \mathrm{~cm})$ is common at the Gao Lagoon midden in Ghana, dated to between $\sim 6-4 \mathrm{ka} .{ }^{136}$ Chenorkian ${ }^{137-138}$ uses the term "generally microlithic" to describe very similar industries from Ivory Coast middens dated from 3.5-1.3ka, which feature crude and small quartz artefacts. Near Abidjan, a similar aceramic industry has been dated to $\sim 13 \mathrm{ka} .{ }^{139}$ 
The earliest indications of a ceramic LSA come from the Ravin de la Mouche site at the Ounjougou locality in Mali, where ceramic sherds have been dated to a minimum age of $\sim 9.4 \mathrm{ka}$ (Fig. 4). ${ }^{140}$ The dates coincide with humid conditions in the Sahara and the pottery is thought to form part of a new subsistence strategy, together with small bifacial arrowheads, exploiting an ecology associated with abundant wild grasses. These early shards are decorated with impressions which were too fragmentary to be identified.

\section{Fig. 4 here}

Later dates of $\sim 8$-6ka are more typical for the emergence of pottery in West Africa and may perhaps signify a change in conditions (e.g., ecological changes, increased sedentism) that made it more advantageous to use ceramic material. ${ }^{141}$ The pottery is most frequently decorated with comb impressions, which characterise southern Saharan/Sahelian ceramics during this time. Groundstone axes appear at the same time. Ceramics appear with LSA assemblages in Iwo Eleru at 4 ka, and seem to appear contemporaneously at Bosumpra in Ghana and Dutsen Kongba in Nigeria. ${ }^{142-}$

${ }^{143}$ Whether the appearance of pottery and ground stone signals a shift in economy or a movement of ideas or peoples from the north is not yet understood and limited studies of human fossils have identified significant differences between Saharan populations and those represented by the Iwo Eleru individual (see below). It is possible that the overlap between the aceramic and ceramic LSA in West Africa represents the presence of different populations and networks employing different lifeways. 
Of further note is the fact that not all ceramic LSA industries are microlithic. Macrolithic LSA assemblages featuring heavy duty elements such as large flaked or ground stone axes, picks, and celts succeed aceramic microlithic at several sites such as Rim in Burkina Faso, and Afikpo in Nigeria, and may reflect the digging of tubers (Fig. 4). ${ }^{144-145}$ Additionally, the persistence or reinvention of prepared core technology is also observed, much as it is in East Africa (e.g., Pleurdeau et al. ${ }^{146}$ ), in association with large scrapers. Such industries are found in poorly dated contexts at a number of sites in West Africa (see MacDonald ${ }^{147}$ and references therein), and have also been reported at Shum Laka in Cameroon. Such macrolithic assemblages can be distinguished from late MSA assemblages (e.g., Scerri et $\mathrm{al}^{148}$ ), which do not simply include prepared core technology, but rather a constellation of pan-African classic MSA elements such as core axes, basally thinned pieces, denticulates and notched tool with no evidence of microliths.

Later ceramic microlithic sites are widely distributed in West Africa from Senegal and the Malian Sahel at Nioro to the forest regions of Liberia, Nigeria, and Cameroon. ${ }^{149}$ This technological base may have persisted up to 1000 years ago at rock shelter sites in the Liberian forest and Sierra Leone. ${ }^{150-151}$ Before or at the inception of the development of agriculture, the late LSA $(\sim 3.5 \mathrm{ka})$ in the forests and savannahs of central Ghana features sandstone "rasps", polished stone axes and bracelets, grindstones, and comb-impressed pottery, as well as a microlithic component. ${ }^{152}$ Described as the 'Kintampo Industry', this culture also extended into southern Ghana and the Ivory Coast and may have been influenced by Saharan groups moving southwards with aridification. ${ }^{153}$ However, the term LSA may no longer be 
appropriate in this context and others have proposed the term SMA (Stone to Metal Age) instead (see e.g., Casey ${ }^{154}$ ), as the Kintampo culture seems to have been relatively sedentary, engaged in the building of durable structures and the beginning of food production. ${ }^{155}$

\section{Fossils}

The earliest human fossils from West Africa date to the Terminal Pleistocene/Early Holocene. Discovered in 1965, the rockshelter of Iwo Eleru in southern Nigeria yielded a human calvaria dating to between $\sim 11.7$ and $16.3 \mathrm{ka} .{ }^{156-158}$ No other West African fossils yet date to a period as early as this. The calvaria is distinctive because it features a mix of archaic and derived features more typical of Middle and Late Pleistocene individuals, than contemporary human populations from elsewhere in Africa. The archaic features of Iwo Eleru's neuro-cranium has suggested introgression of archaic genes into the modern human gene pool to some researchers (see below), or the survival of populations with archaic morphology in regions of Africa more recently than previously assumed. ${ }^{159-162}$ The fossils date to the same timeframe as the final MSA in Senegal albeit in a different cultural context, which provides independent evidence to support the persistence of both biologically and culturally 'anachronistic' populations in West Africa.

The fossil has also been analysed to evaluate population-level hypotheses regarding early and mid-Holocene population expansions. In particular, West Africa is one of the potential source areas for populations expanding into the Sahara with the onset of the African Humid Period. However, there are significant morphological differences between the Iwo Eleru specimen and early Holocene samples, including those from 
Gobero ( 10ka) in the Sahara. ${ }^{163}$ These results that suggest that the peopling of the Sahara during the Holocene did not, at least immediately, involve populations from tropical West Africa.

\section{Genetics}

There is no ancient DNA from West Africa at present. Genetic studies have instead focused on contemporary DNA to infer past demographic processes in West Africa. However, this has proved to be extremely problematic, and results are often uncritically incorporated into narratives of past demographic changes. Gene trees are not population histories and West African demographic history, as with most of the rest of the African continent, was complex. The distributions of modern populations cannot be taken to reflect those of past populations, thus problematizing many of the conclusions in genetic phylogeography.

On the other hand, genetic research has been much quicker to recognise West Africa's potential in studies of human origins, compared to archaeology. Continentally distributed fossil and genetic lines of evidence have suggested for sometime that a high degree of population structure (subdivision) existed in the African Pleistocene. ${ }^{164-166}$ This structure appears to have both significant time depth and persistence across the African continent. Although the Iwo Eleru calvaria is unique in West Africa, a few Late Pleistocene specimens from Central Africa exhibit comparable features, suggesting that West and Central African Pleistocene populations may have been relatively isolated from others in North, East and Southern Africa (e.g., Crevecoeur et al. ${ }^{167}$ ). Both regions are now also associated with possible late surviving archaic human introgression into the modern human gene pool. ${ }^{168-170}$ 
However, without an archaic reference genome, it is currently difficult to test these models. Despite this, the recognition of African Multiregionalism, along with the complex hybridization processes now known to have taken place in Eurasia have opened up new realms of possibilities. In this context, models of archaic-modern human hybridization within Africa itself, and the late persistence of archaic populations in backwaters and isolated regions of the continent are entirely possible.

\section{Conclusion: the West African record in context}

The extent of the connection between evolutionary processes in West Africa and other regions of the continent remains to be evaluated through future studies and discoveries. However, it seems clear that such a connection did exist, and its importance may have been varied across the timespan of the Pleistocene. West Africa may have provided important refuges for populations during glacial cycles, and at least three such refugia have been identified in this region. ${ }^{171-173}$ Alternatively, parts of West Africa may have repeatedly acted as ecological bottlenecks, with isolated populations persisting in areas far from the riparian networks of the eastern half of Africa. Such populations could have included archaic human groups as well as culturally anachronistic Homo sapiens using MSA technologies long replaced in other regions of Africa. Such cycles of repeated isolation and interaction represent powerful mechanisms for creating biological and cultural complexity, which may have ultimately affected diverse populations living across Africa. Certainly, as each region of Africa becomes better understood, both its archaeological signature and relationships with other regions become apparent. This is also likely to be the case with West Africa. 
Two major questions therefore concern whether humans ever significantly inhabited forests before the Holocene and how much of an ecological barrier forests represented to different populations (e.g., Mercader ${ }^{174}$; Roberts and Petraglia ${ }^{175}$ ). Like Central Africa, large swathes of West Africa are forested, and fieldwork in these regions has been limited by challenging conditions and poor preservation (see e.g., Taylor ${ }^{176}$ for discussion). While forested regions have long been considered as hostile environments to humans, enough ethnographic and botanical research now exists to make the case that low density groups, such as hunter-gatherers, would have had enough resources to live in these ecozones. ${ }^{177-180}$ Determining whether huntergatherers did indeed exploit such resources is a major research goal.

In later time periods, the research emphasis shifts to the role of forests in keeping different populations apart. It appears that population diversity in West Africa was also more significant than hitherto considered prior to the significant extinction of hunter-gatherer diversity and expansion of farmers and later societies. ${ }^{181}$ In later prehistory, the role of West Africa as the source of Holocene and post Holocene population expansions into North Africa and other regions of the continent also remains a matter of debate (e.g. MacDonald ${ }^{182}$; Drake et al. ${ }^{183}$; Stojanowski ${ }^{184}$ ). However, the resolution of recent climate records at least allows tentative correlations between the drying of the Sahara and the southwards movements of its populations into Sahelian and tropical zones. Such processes, linked to the rise of politically complex societies, against emphasises the place of West Africa in wider, pan-African processes of demographic movement and cultural change. 


\section{Primary Sources}

Artefacts from the West African Stone Age are held in several key repositories. In Senegal, the main repository is at IFAN, which holds artefacts from across the West African region. In Nigeria, the Jos Museum contains the most significant collection of Stone Age artefacts in the country. Further important collections are held at the universities of Ibadan, Zaria, and Nsukka. In Ghana, artefacts are held in regional museums, including the National Museum, all managed by the Ghana Museums and Monments Board, and the University of Ghana, Legon. In the Ivory Coast, the Musée des Civilisations de Côte d'Ivoire contains artefacts from the region, however many West African Stone Age artefacts are also held at various museums in France.

\section{Further Reading}

1. Allsworth-Jones, P. 1986. Middle Stone Age and Middle Palaeolithic: the evidence from Nigeria and Cameroun. In: G.N. Bailey, P. Callow (Eds.), Stone Age Prehistory. Cambridge University Press: Cambridge. pp. 153-68.

2. Chevrier, B., Rasse, M., Lespez, L., Tribolo, C., Hajdas, I., Guardiola, M., Lebrun, B., Leplongeon, A., Camara, A., Huysecom, E. 2016. West African Palaeolithic history: New archaeological and chronostratigraphic data from the Falémé valley, eastern Senegal. Quaternary International 408, 33-52. 
3. De Barros, P. 1990. Changing paradigms, goals and methods in the archaeology of francophone West Africa. In P. Robertshaw (Ed.), A History of African Archaeology, pp. 155-172. James Curry: London.

4. Diop, A. 2000. Les industries du Paléolithique post-acheuléen au Sénégal. In R. Vernet (Ed.), L'Archéologie en Afrique de l'Ouest. Sahara et Sahel. Editions Sépia: Saint-Maur, France. pp. 257- 268.

5. Gunz, P., Bookstein, F.L, Mitteroecker, P., Stadlmayr, A., et al. 2009. Early modern human diversity suggests subdivided population structure and a complex out-of-Africa scenario. Proceedings of the National Academy of Sciences USA, 106: 6094-6098.

6. Hammer, M.F., Woerner, A.E., Mendez, F.L., Watkins, J.C., Wall, J.D. 2011. Genetic evidence for archaic admixture in Africa. Proceedings of the National Academy of Sciences USA, 108: 15123- 15128.

7. Harvati, K., Stringer, C.B., Grün, R., Aubert, M., Allsworth-Jones, P., et al. 2011. The Later Stone Age Calvaria from Iwo Eleru, Nigeria: Morphology and Chronology. PLoS ONE 6(9): e24024. doi: 10.1371/journal.pone.0024024

8. Hawkins, A., Casey, J., Godfrey-Smith, D., D’Andrea, A.C. 1996. A Middle Stone Age component at the Birimi site, Northern Region, Ghana. Nyame Akuma 46, 34-36. 
9. Huysecom, E., Rasse, M., Lespez, L., Neumann, K., Fahmy, A., Ballouche, A., Ozainne, S., Maggetti, M., Tribolo, C. and Soriano, S. 2009. The emergence of pottery in Africa during the tenth millennium cal BC: new evidence from Ounjougou (Mali). Antiquity, 83, 905-917.

10. Kense, F.J. 1990. Archaeology in Anglophone West Africa. In P. Robertshaw (Ed.), A History of African Archaeology, pp. 135-154. James Curry: London.

11. Lebrun, B., Tribolo, C., Chevrier, B., Rasse, M., et al. 2016. Establishing a West African chrono- cultural framework: First luminescence dating of sedimentary formations from the Falémé Valley, Eastern Senegal. Journal of Archaeological Science Reports, 7: 379-388.

12. Mercader, J. 2002. Forest people: The role of African rainforests in human evolution and dispersal. Evolutionary Anthropology, 11: 117-124.

13. MacDonald, K.C., 1998. Archaeology, language and the peopling of West Africa: a consideration of the evidence. In: Blench, R., Spriggs, M. (Eds.), Archaeology and Language II: Archaeological Data and Linguistic Hypotheses. Routledge, London, pp. 33-66.

14. McKintosh, S.K. 2001. West African Later Stone Age. In P. Peregrine and M. Ember (eds.), Encyclopedia of Prehistory Volume 1: Africa, pp. 319-322. Springer US. 
15. McIntosh, S.K and McIntosh, R.J. 1983. Current Directions in West African Prehistory. Annual Review of Anthropology 121, 215-258.

16. Miller, C.S., Gosling, W.D. 2014. Quaternary forest associations in lowland tropical West Africa. Quaternary Science Reviews, 84: 7-25.

17. Nygaard, S., Talbot, M.R. 1984. Stone age archaeology and environment on the Southern Accra plains, Ghana. Norwegian Archaeological Review 17, 19-38.

18. Quickert, N.A., Godfrey-Smith, D.I., Casey, J.L. 2003. Optical and thermoluminescence dating of Middle Stone Age and Kintampo bearing sedmients at Birimi, a multi-component archaeological site in Ghana. Quaternary Science Reviews 22, 1291-1297.

19. Robert, A., Soriano, S., Rasse, M., Stokes, S. And Huysecom, E. 2003. First chrono-cultural reference framework for the West African Paleolithic: New data from Ounjougou, Dogon Country, Mali. Journal of African Archaeology 1, 151169.

20. Scerri, E.M.L., Blinhorn, J., Groucutt, H.S., Niang, K. 2016. The Middle Stone Age archaeology of the Senegal River Valley. Quaternary International, 408: 1632.

21. Scerri, E.M.L, Blinkhorn, J., Niang, K., Bateman, M., Groucutt, H.S. 2017. Persistence of Middle Stone Age technology to the Pleistocene/Holocene 
transition supports a complex hominin evolutionary scenario in West Africa.

Journal of Archaeological Science Reports 11, 639-646.

22. Shaw, C.T. 1978-1979. Holocene adaptations in West Africa: the Late Stone Age. Early Man News 3-4, 51-81.

23. Soriano, S., Rasse, M., Tribolo, C. and Huysecom, E. 2010. Ounjougou: a long Middle Stone Age sequence in the Dogon country (Mali), in: P. Allsworth-Jones (ed.) West African archaeology. New developments, new perspectives (BAR International series 2164): 1-14. Oxford: Archaeopress.

24. Wall, J.D., Lohmueller, K.E., Plagnol, V. 2009. Detecting Ancient Admixture and Estimating Demographic Parameters in Multiple Human Populations. Molecular Biology and Evolution, 26:1823-1827.

25. Watson, D.J. 2010. Within savanna and forest: A review of the Late Stone Age Kintampo Tradition, Ghana. Azania 45, 141-174.

\section{Notes}

${ }^{1}$ CS Miller and WD Gosling, 'Quaternary forest associations in lowland tropical West Africa', Quaternary Science Reviews 84, (2014): 7-25.

${ }^{2} \mathrm{~F}$ White, The vegetation of Africa, a descriptive memoir to accompany the UNESCO/AETFAT/UNSO Vegetation Map of Africa (3 Plates, Northwestern Africa, Northeastern Africa, and Southern Africa, 1:5,000,000). (Paris: UNESCO, 1983). ${ }^{3}$ TC Whitmore, An Introduction to Tropical Rainforests. 2nd ed. (Oxford: Oxford University Press, 1998).

${ }^{4}$ Y Malhi and J Wright, 'Spatial patterns and recent trends in the climate of tropical rainforest regions', Philosophical Transactions of the Royal Society B 359 (2004): 311-329. 
${ }^{5}$ P Zelazowski et al., 'Changes in the potential distribution of humid tropical forests on a warmer planet', Philosophical Transactions of the Royal Society A 369, (2011): 137-160.

${ }^{6} \mathrm{ME}$ Leal, 'The past protecting the future: locating climatically stable forests in West and Central Africa', International Journal of Climate Change Strategy and Management 1, (2009): 92-99.

${ }^{7}$ J Kingdon, The Kingdon FieldGuide to African Mammals: Second Edition. (New Jersey: Princeton University Press, 2015).

${ }^{8}$ EML Scerri, 'On the spatial and technological organisation of hafting modifications in the North African Middle Stone Age', Journal of Archaeological Science 40, (2013): 4234-4248.

${ }^{9}$ EML Scerri et al., 'Earliest Evidence for the Structure of Homo sapiens Populations in Africa', Quaternary Science Reviews 101, (2014): 207-216.

${ }^{10}$ EML Scerri, 'The North African Middle Stone Age and its place in recent human evolution', Evolutionary Anthropology 26, (2017): 119-135.

${ }^{11}$ W Bishop, 'Discussion in terminology', in Background to Evolution in Africa, eds. W Bishop and JD Clark, (Chicago: University of Chicago Press, 1967), 861-875. ${ }^{12}$ EML Scerri et al., 'Unexpected technological heterogeneity in northern Arabia indicates complex Late Pleistocene demography at the gateway to Asia', Journal of Human Evolution 75, (2014): 125-142.

${ }^{13}$ HS Groucutt and J Blinkhorn, 'The Middle Palaeolithic in the desert and its implications for understanding hominin adaptation and dispersal', Quaternary International 300, (2013): 1-12.

${ }^{14}$ B Lebrun et al., 'Establishing a West African chrono- cultural framework: First luminescence dating of sedimentary formations from the Falémé Valley, Eastern Senegal', Journal of Archaeological Science Reports 7, (2016): 379-388.

${ }^{15}$ EML Scerri et al., 'Persistence of Middle Stone Age technology to the Pleistocene/Holocene transition supports a complex hominin evolutionary scenario in West Africa', Journal of Archaeological Science Reports 11, (2017): 639-646.

${ }^{16} \mathrm{KC}$ MacDonald, 'Archaeology, language and the peopling of West Africa: a consideration of the evidence', in Archaeology and Language II: Archaeological Data and Linguistic Hypotheses, eds. R Blench and M Spriggs, (London: Routledge, 1998), 33-66.

${ }^{17}$ CM Stojanowski, 'Iwo Eleru's place among Late Pleistocene and Early Holocene populations of North and East Africa', Journal of Human Evolution 75, (2014): 8089.

${ }^{18}$ AB Stahl, 'Intensification in the West African Late Stone Age', in The archaeology of Africa: food, metals and towns, eds. T Shaw, P Sinclair, B Andah and A Okpoko, (London: Routledge, 1993), 261-273.

${ }^{19}$ MacDonald, "Archaeology, language and the peopling of West Africa", 33-36.

${ }^{20} \mathrm{D}$ Richter et al., 'The age of the hominin fossils from Jebel Irhoud,Morocco, and the origins of the Middle Stone Age', Nature 546, (2017): 293-296

${ }^{21}$ FJ Kense, 'Archaeology in Anglophone West Africa', in History of African Archaeology, ed. P Robertshaw, (London: James Curry, 1990), 135-154.

${ }^{22} \mathrm{P}$ De Barros, 'Changing paradigms, goals and methods in the archaeology of francophone West Africa', in History of African Archaeology, ed. P Robertshaw, (London: James Curry, 1990), 155-172.

${ }^{23}$ EML Scerri, 'The Aterian and its place in the North African Middle Stone Age', Quaternary International 300, (2013): 111-130. 
${ }^{24}$ JD Fage, 'Evolution de l'histographie de l'Afrique', in Histoire general de l'Afrique I: méthodologie et préhistoire Africaine, ed. J Ki-Zerbo, (New York: Unesco, 1980), 45-53.

${ }^{25}$ AJH Goodwin and C Van Riet Lowe, 'The Stone Age cultures of South Africa', Annals of the South African Museum 27, (1929): 1-289.

${ }^{26}$ Kense, "Archaeology in Anglophone West Africa," 135-154.

${ }^{27}$ De Barros, "Changing paradigms, goals and methods," 155-172.

${ }^{28} \mathrm{R}$ Mauny, 'Les recherches archéologiques en A.O.F., particulierement de 1938 á 1952', Bulletin de l'Institut Français d'Afrique Noire 15, (1953): 684-730.

${ }^{29}$ O Davies, West Africa Before the Europeans (London: Methuen \& Co., 1967).

${ }^{30}$ Kense, "Archaeology in Anglophone West Africa," 135-154.

${ }^{31}$ Mauny, "Les recherches archéologiques en A.O.F.," 684-730.

${ }^{32} \mathrm{R}$ Mauny, 'Tableau géographique de l'Ouest Africain au Moyen Age, d'après les sources écrites, la tradition, et l'archéologie', Mémoire de l'Institut Français d'Afrique Noire 61, (1961).

${ }^{33}$ B Fagg, 'An outline of the Stone Age of the plateau Minesfield', Proceedings of the $3^{\text {rd }}$ International West African Conference, Ibadan, 1949, (1956): 203-222.

${ }^{34}$ Davies, West Africa Before the Europeans.

${ }^{35}$ De Barros, "Changing paradigms, goals and methods," 155-172.

${ }^{36}$ CA Diop, Nations nègres et culture (Paris: Collection Présence Africaine, 1955)

${ }^{37}$ CA Diop, L'Afrique noire précoloniale (1 Paris: Collection Présence Africaine, 1960)

${ }^{38}$ CA Diop, 'Résponses à quelques critiques', Bulletin de l'Institut Français d'Afrique Noire 24, (1962): 542-74.

${ }^{39}$ CA Diop, Antériorité des civilisations Nègres: mythe ou verité historique? (Paris: Collection Présence Africaine, 1967).

${ }^{40} \mathrm{~F}$ Bordes, Typologie du Paléolithique ancien et moyen (Delmas, Publications de l'Institut de Préhistoire de l'Université de Bordeaux, Mémoire n 1, 1961).

${ }^{41}$ HJ Hugot, 'Archaeology in Senegal, Mali, Mauritania and Guinea. Discussion' in Report on Conference of West African Archaeologists, at Freetown, 28-30 June 1966, ed. T Shaw, West African Archaeological Newsletter 5, (1966): 36-52.

${ }^{42} \mathrm{P}$ Allsworth-Jones, 'Middle Stone Age and Middle Palaeolithic: the evidence from Nigeria and Cameroun' in Stone Age Prehistory, eds. GN Bailey and P Callow, (Cambridge: Cambridge University Press, 1986), 153-68.

${ }^{43}$ EML Scerri et al., 'The Middle Stone Age of the Senegal River Valley', Quaternary International 408, (2016): 16-32.

${ }^{44}$ Th Dagan, 'Le site préhistorique de Tiemassas (Sénégal)', Bullettin de l'IFAN 18, (1956): 432-461.

${ }^{45} \mathrm{C}$ Descamps and D Démoulin, 'Stratigraphie du gisement préhistorique du Cap Manuel (Dakar)', Bulletin de l'Institut Français d'Afrique Noire 31, (1969): 739-51. ${ }^{46}$ Davies, West Africa Before the Europeans.

${ }^{47} \mathrm{JH}$ Hugot, 'Le Paléolithique terminal dans l'afrique de l'ouest', in Background to Evolution in Africa, eds. WW Bishop and JD Clark, (London and Chicago: University of Chicago Press, 1967), 529-555.

${ }^{48} \mathrm{~K}$ Niang and M Ndiaye, 'The Middle Palaeolithic of West Africa: Lithic technotypological analyses of the site of Tiemassas, Senegal', Quaternary International 408, (2016): 4-15.

49 JH Atherton, 'Archaeology in Liberia: problems and possibilities', West African Archaeological Newsletter 11, (1969): 19-21.

${ }^{50}$ JH Atherton, 'Liberian Prehistory', Liberian Studies Journal 3, (1970): 83-111. 
${ }^{51} \mathrm{C}$ Gabel et al., 'Preliminary Report on an Archaeological Survey of Liberia', Liberian Studies Journal 5, (1975): 87-105.

${ }^{52}$ Allsworth-Jones, "Middle Stone Age and Middle Palaeolithic," 153-168.

${ }^{53}$ RC Soper, 'The Stone Age in Northern Nigeria, Journal of the Historical Society of Nigeria 3, (1956): 175-194.

${ }^{54} \mathrm{R}$ Chenorkian and G Paradis, 'Une industrie Paléolithique découverte dans la « Terre de Barre » d'une terrasse proche d'Anyama (region d'Abidjan)', Nyame Akuma 21, (1982): 18-27.

${ }^{55}$ SE Nygaard and M Talbot, 'Interim report on the excavations at Asokrochona, Ghana', West African Journal of Archaeology 6, (1976): 13-19.

${ }^{56} \mathrm{~N}$ Taylor, 'Across rainforests and woodlands: a systematic reappraisal of the Lupemban Middle Stone Age in Central Africa', in Africa from MIS 6 to 2:

Population Dynamics and Palaeoenvironments, eds. SC Jones and BA Stewart (Dordrecht: Springer: Dordrecht, 2016), 273-300.

${ }^{57} \mathrm{P}$ Roberts and MD Petraglia, 'Pleistocene rainforests: barriers or attractive environments for early human foragers?', World Archaeology 46, (2015): 718-739.

${ }^{58}$ Scerri, "Persistence of Middle Stone Age technology," 639-646.

${ }^{59} \mathrm{~J}$ Casey, 'The Stone to Metal Age in West Africa', in The Oxford Handbook of African Archaeology, eds. P Mitchell and P Lane, (Oxford: Oxford University Press, 2013), 603-614.

${ }^{60} \mathrm{~J}$ Maley, 'The African rain forest - main characteristics of changes in vegetation and climate from the Upper Cretaceous to the Quaternary', Proceedings of the Royal Society of Edinburgh Biological Sciences 104 (1996): 31-73.

${ }^{61} \mathrm{~S}$ Jahns et al., 'Vegetation and climate history of west equatorial Africa based on a marine pollen record off Liberia (site GIK 16776) covering the last 400,000 years', Review of Palaeobotany and Palynology 102, (1998): 277-288.

${ }^{62}$ LM Dupont et al., 'Vegetation change in equatorial West Africa: Time-slices for the last 150 ka', Palaeogeography, Palaeoclimatology, Palaeoecology 155, (2000): 95122.

${ }^{63}$ Miller and Gosling, "Quaternary Forest Associations," 7-25.

${ }^{64}$ Roberts and Petraglia, "Pleistocene Rainforests," 718-739.

${ }^{65}$ McIntosh and McIntosh, 1983

${ }^{66}$ A Camara and B Duboscq, 'La fouille d'un site Acheuléen a Djita (Basse Vallee de la Falémé, Sénégal', L'Anthropologie 94, (1990): 293-304.

${ }^{67}$ ibid

${ }^{68}$ A Camara and B Duboscq, 'Le gisement préhistorique de Sansandé, Basse Vallee de la Falémé, Sénégal: approche typologique et stratigraphique', L'Anthropologie 88, (1984): 377-402.

${ }^{69}$ A Camara and B Duboscq, 'Contexte chronostratigraphique des outillages du paléolithique evolué dans l'est du Sénégal', L'Anthropologie 91, (1987): 511-519.

${ }^{70}$ Camara and Duboscq « La fouille d'un site Acheuléen, » 293-304.

${ }^{71}$ Lebrun, "Establishing a West African chrono- cultural framework," 379-388.

${ }^{72}$ Davies, West Africa.

${ }^{73}$ CT Shaw, 'Holocene adaptations in West Africa: the Late Stone Age', Early Man News 3-4, (1978-79): 51-81.

${ }^{74}$ FN Anozie, "Recent archaeological discoveries in south-eastern Nigeria", (paper presented at the annual congress of the Historical Society Nigeria, 27 ${ }^{\text {th }}$, Port Harcourt, 1982).

${ }^{75}$ Soriano, "Ounjougou," 1-14.

${ }^{76}$ Taylor, "Across rainforests and woodlands," 273-300. 
${ }^{77}$ Nygaard and Talbot, "Interim report," 13-19.

78 ibid

${ }^{79}$ ibid

${ }^{80}$ ibid

${ }^{81}$ Quickert, "Optical and thermoluminescence daing," 1291-1297.

${ }^{82}$ A Ravisé, 'Recensement des sites paléolithiques et néolithiques du Sénégal', Bulletin de l'Institut Français d'Afrique Noire 37, (1975): 234-245.

${ }^{83}$ A Camara, 'Le Paléolithique ancien', in L'Archéologie en Afrique de l'Ouest Sahara et Sahel, ed. R Vernet, (Editions Sépia., 2000), 239-256.

${ }^{84}$ A Diop, 'Les industries du Paléolithique post-acheuléen au Sénégal', in

L'Archéologie en Afrique de l'Ouest Sahara et Sahel, ed. R Vernet, (Editions Sépia., 2000), 257-268.

${ }^{85}$ Scerri, "The Middle Stone Age," 16-32.

${ }^{86} \mathrm{~F}$ Laforgue, 'État actuel de nos conaissances sur la préhistoire en Afrique

Occidental Française', Bulletin du Comité d'Études historiques et scientifiques de l'A.O.F. 7, (1925): 105-171.

${ }^{87} \mathrm{H}$ Hubert, 'Objets anciens de l'Afrique Occidentale', Bulletin du Comité d'études, historiques et scientifiques de l'AOF 5, (1922): 382-399.

${ }^{88} \mathrm{P}$ Laforgue and R Mauny, 'Contribution à la préhistoire du cap-vert', Bulletin $d u$ Comité d'Etudes Historiques et Scientifiques de l'Afrique Occidentale Française 21, (1938): 325-343.

${ }^{89} \mathrm{R}$ Corbeil et al., 'Préhistoire et protohistoire de la presqu'île de Cap-vert' Bulletin de l'IFAN, série $\mathrm{B}$, tome $\mathrm{X},(1948)$ : 378-460.

${ }^{90} \mathrm{R}$ Mauny, 'Sur la préhistoire de la presqu'île du Cap Vert', Etudes Sénégalaises 1, l'Institut Français d'Afrique Noire, (1949): 239-251.

${ }^{91}$ R Mauny, 'Découverte d'un biface Acheuléen à Dakar', Notes Africaines 45, (1950): 3-4.

${ }^{92} \mathrm{~F}$ Richard, 'Contribution à l'étude de la stratigraphie du quaternaire de la Presqu'île du Cap-Vert (Sénégal)', Bulletin de la Société préhistorique de France 52, (1955): 80-88.

${ }^{93}$ Dagan, « Le site préhistorique, », 432-461.

${ }^{94}$ Th Dagan, 'Les gisements préhistoriques de Tiémassas et de Pointe Sarène', Actes du VIeme Congress Panafrique Préhistoire Chambery, (1972): 92-94.

${ }^{95}$ Hugot, « Le Paléolithique terminal, » 529-555.

${ }^{96} \mathrm{C}$ Descamps, Contribution à la préhistoire de I'Ouest Sénégalais. Travaux et Documents, volume II (Université de Dakar, Faculté des Lettres et Sciences Humaines, Département d'Histoire, 1979).

${ }^{97}$ A Diop, 'Contribution la connaissance du Paléolithique post-acheuléen dans la presqu'île du Cap-Vert' Mémoire de maîtrise Université Cheikh Anta Diop de Dakar (unpublished, 1976).

${ }^{98}$ A Diop, 'Découverte d'un biface à Biseau terminal à Djita (Sénégal Oriental)', Notes Africaines, $\mathrm{n}^{\circ} 167$ (1980).

${ }^{99}$ Diop, «Les industries du Paléolithique , » 257-268.

${ }^{100} \mathrm{R}$ Mauny, 'Contribution a la pre histoire et a la protohistoire de la re gion de $\mathrm{Ke}$ dougou (Se ne gal Oriental)', Bulletin de la Société Anthropologique de Paris 1, (1963): 113-122.

${ }^{101} \mathrm{C}$ Barbey and C Descamps, 'A propos de galets ame nage s de la moyenne Gambie', Bulletin de l'Association Sénégalaise pour l'Étude du Quaternaire de l'Ouest Africain 18, (1968): 19-22.

${ }^{102}$ Camara and Duboscq, « Le gisement préhistorique de Sansandé, » 377-402. 
${ }^{103}$ B Chevrier et al., 'West African Palaeolithic history: New archaeological and chronostratigraphic data from the Falémé valley, eastern Senegal', Quaternary International 408, (2016): 33-52.

${ }^{104}$ Lebrun, "Establishing a West African chrono- cultural framework," 379-388.

${ }^{105}$ Scerri, "Persistence of Middle Stone Age technology," 639-646.

${ }^{106}$ Lebrun, "Establishing a West African chrono- cultural framework," 379-388.

${ }^{107}$ Scerri, "Persistence of Middle Stone Age technology," 639-646.

${ }^{108}$ Niang and Ndiaye, "The Middle Palaeolithic of West Africa," 4-15.

109 ibid

${ }^{110}$ Allsworth-Jones, "Middle Stone Age and Middle Palaeolithic," 153-168.

${ }^{111}$ Fagg, "An outline of the Stone Age," 203-222.

${ }^{112}$ Soper, "The Stone Age," 175-194.

113 ibid

114 ibid

${ }^{115} \mathrm{~F}$ Anozie, “Contribution à l'étude de la préhistoire de l'Afrique occidentale" (PhD diss., University of Bordeaux 1, 1975).

${ }^{116} \mathrm{P}$ Allsworth-Jones, 'The Middle Stone Age north of the Jos Plateau: a preliminary report', West African Journal of Archaeology 11, (1985): 1-24.

${ }^{117}$ Allsworth-Jones, "Middle Stone Age and Middle Palaeolithic," 153-168.

${ }^{118}$ A Marliac, 'L'état des connaissances sur le paléolithique et le néolithique d Cameroun', Colloque International du CNRS, Contribution à la Recherche

Ethnologique a l'Histoire des Civilisations du Cameroun (Paris.1973). 1-45.

${ }^{119}$ Marliac and Gavaud, «Premiers éléments d'une séquence paléolithique, » 53-66.

${ }^{120}$ Allsworth-Jones, "Middle Stone Age and Middle Palaeolithic," 153-168.

121 ibid

${ }^{122}$ Soriano, "Ounjougou," 1-14.

123 ibid

${ }^{124}$ S Soriano, 'Quand archaïque n'est pas ancien! Étude de cas dans le Paléolithique du Pays dogon (Ounjougou, Mali)", Annales de la Fondation Fyssen 18, (2003): 7992.

${ }^{125} \mathrm{M}$ Rasse et al., 'La séquence pléistocène supérieur d'Ounjougou (Pays dogon, Afrique de l'Ouest): évolution géomorphologique, enregistrements sédimentaires et changements culturels', Quaternaire 15, (2004): 329-41.

${ }^{126}$ A Robert et al., 'First chrono-cultural reference framework for the West African Paleolithic: New data from Ounjougou, Dogon Country, Mali', Journal of African Archaeology 1, (2003): 151-169.

${ }^{127}$ VP Liubin and FY Guédé, Paleolit Respubliki Kot d'Ivvuar (Zapadnaya Afrika) (The Palaeolithic of the Republic of Cote d'Ivoire (West Africa) (Vol. 3), (St.

Petersburg: Russian Academy of Sciences, Institute of the History of Material Culture Proceedings, 2000).

${ }^{128}$ P Allsworth-Jones, "the Palaeolithic of Republic Cote d'Ivoire (West Africa)" review of Paleolit Respubliki Kot d'Ivuar (Zapadnaya Afrika) by VP Liubin and FY. Guédé, Antiquity 76, (2002): 578.

${ }^{129}$ SK McKintosh, 'West African Later Stone Age' in Encyclopedia of Prehistory Volume 1: Africa, eds. P Peregrine and M Ember, (Springer US, 2001), 319-322.

${ }^{130} \mathrm{~J}$ Moeyersons, 'Geomorphological processes and their palaeoenvironmental significance at the Shum Laka cave (Bamenda, western Cameroon)', Palaeogeography, Palaeoclimatology, Palaeoecology 133, (1997): 103-116.

${ }^{131}$ Cornelissen, "On microlithic quartz industries," 1-24.

${ }^{132}$ Cornelissen, "Human responses to changing environments," 197-235. 
${ }^{133}$ Lebrun, "Establishing a West African chrono- cultural framework," 379-388.

${ }^{134}$ T Shaw, 'Finds at the Iwo Eleru rock shelter, western Nigeria', Voir Réf 16 (1973): 190-92.

${ }^{135}$ SK McIntosh and RJ McIntosh, 'Current Directions in West African Prehistory', Annual Review of Anthropology 121, (1983): 215-258.

${ }^{136}$ S Nygaard and MR Talbot, 'First dates for coastal sites near Kpone, Ghana', Nyame Akuma 11, (1977): 29-30.

${ }^{137} \mathrm{R}$ Chenorkian, Prospections pre- historiques en Cote d'ivoire. Les sites de EhaniaKrinjabo and Kong (Travaux du Laboratoire d'Anthropologie, de Préhistoire et d'Ethnologie de la Méditerranée Occidentale Aix-en-Provence, 1979).

${ }^{138} \mathrm{R}$ Chenorkian, 'Note sur l'industrie lithique de l'amas coquiller de N'Gaty (Basse Cote d'lvoire)', Bulletin de la Société préhistorique française (1982): 284-288.

${ }^{139} \mathrm{R}$ Chenorkian et al., Une industrie microlithique datée de l3050 BP environ decouverte en Cote d'Ivoire dans la "terre de barre" (Trav. du LAPMO, Aix enProvence, 1982).

${ }^{140}$ E Huysecom, et al., 'The emergence of pottery in Africa during the tenth millennium cal BC: new evidence from Ounjougou (Mali)', Antiquity, 83, (2009): 905-917.

${ }^{141}$ Casey, "The Stone to Metal Age," 603-614.AB Smith, 'Radiocarbon dates from Bosumpra Cave, Abetifi, Ghana', Proceedings of the Prehistoric Society. 41, (1975): 179-82.

${ }^{142}$ RN York, 'Excavations at Dutsen Kongba, Plateau State, Nigeria', West African Journal of Archaeology 8, (1978): 139-163.

${ }^{143}$ BW Andah, 'Excavations at Rim, Upper Volta', West African Journal of Archaeology 8, (1978): 75-138.

${ }^{144}$ Shaw, "Holocene adaptations in West Africa," 51-81.

${ }^{145}$ D Pleurdeau et al., 'Cultural change or continuity in the late MSA/Early LSA of southeastern Ethiopia? The site of Goda Buticha, Dire Dawa area', Quaternary International 343, (2012): 117-135.

${ }^{146}$ Shaw, "Holocene adaptations in West Africa," 51-81.

${ }^{147}$ MacDonald, "Archaeology, language and the peopling of West Africa", 33-36.

${ }^{148}$ Scerri, "Persistence of Middle Stone Age technology," 639-646.

${ }^{149}$ McIntosh and McIntosh, "Current Directions," 215-258.

${ }^{150} \mathrm{C}$ Gabel, 'Microlithic occurrences in the Republic of Liberia', West African Journal of Archaeology 6, (1976): 21-35.

${ }^{151} \mathrm{H}$ Atherton, 'Excavations at Kamabai and Yagala rock shelters, Sierra Leone', West African Journal of Archaeology 2, (1972): 39-74.

${ }^{152} \mathrm{D}$ Watson, 'Within savanna and forest: A review of the Late Stone Age Kintampo Tradition, Ghana', Azania 45, (2010): 141-174.

${ }^{153}$ MacDonald, "Archaeology, language and the peopling of West Africa", 33-36.

${ }^{154}$ Casey, "The Stone to Metal Age," 603-614.

${ }^{155}$ Watson, "Within savannah and forest," 141-174.

${ }^{156}$ T Shaw, 'Excavations at Iwo Eleru, 1965', The West African Archaeological

Newsletter 3, (1965): 15-16

${ }^{157}$ Shaw, "Finds at the Iwo Eleru rock shelter", 190-92.

${ }^{158}$ K Harvati et al., 'The Later Stone Age Calvaria from Iwo Eleru, Nigeria:

Morphology and Chronology', PLoS ONE 6, (2011): e24024.

${ }^{159}$ MF Hammer et al., 'Genetic evidence for archaic admixture in Africa', Proceedings of the National Academy of Sciences USA 108, (2011): 15123- 15128. 
${ }^{160}$ JR Stewart and CB Stringer, 'Human evolution out of Africa: the role of refugia and climate change', Science 335, (2012): 1317-1321. 'jêp?

${ }^{161}$ FL Mendez et al., 'An African American Paternal Lineage Adds an Extremely Ancient Root to the Human Y Chromosome Phylogenetic Tree', American Journal of Human Genetics 92, (2013): 454-459.

${ }^{162}$ CB Stringer, 'The Origin and Evolution of Homo sapiens. Philosophical Transactions of the Royal Society B 371, (2016): 20150237.

${ }^{163}$ Stojanowski, "Iwo Eleru's place," 80-89.

${ }^{164} \mathrm{P}$ Gunz et al., 'Early modern human diversity suggests subdivided population structure and a complex out-of-Africa scenario', Proceedings of the National Academy of Sciences USA 106, (2009): 6094-6098.

${ }^{165}$ A Scally and R Durbin, 'Revising the human mutation rate: implications for understanding human evolution', Nature Reviews Genetics 13, (2012): 745-753.

${ }^{166} \mathrm{O}$ Mazet et al., 'On the importance of being structured: instantaneous coalescence rates and human evolution-lessons for ancestral population size inference?' Heredity 116, (2016): 362-371.

${ }^{167}$ I Crevecoeur et al., 'Late Stone Age human remains from Ishango (Democratic Republic of Congo): New insights on Late Pleistocene modern human diversity in Africa', Journal of Human Evolution 96, (2016): 35-57.

168 JD Wall et al., 'Detecting Ancient Admixture and Estimating Demographic Parameters in Multiple Human Populations', Molecular Biology and Evolution 26, (2009):1823-1827.

${ }^{169}$ Hammer, "Genetic Evidence," 15123- 15128.

${ }^{170}$ Mendez, "An African American," 454-459.

${ }^{171}$ Malhi and Wright, "Spatial patterns," 311-329.

${ }^{172}$ Leal, "The past protecting the future," 92-99.

${ }^{173}$ Kingdon, The Kingdon Field Guide.

${ }^{174} \mathrm{~J}$ Mercader, 'Forest people: The role of African rainforests in human evolution and dispersal', Evolutionary Anthropology 11, (2002): 117-124.

${ }^{175}$ Roberts and Petraglia, "Pleistocene rainforests," 718-739.

176 Taylor, "Across rainforests and woodlands," 273-300.

${ }^{177}$ A Hladik and E Dounias, 'Wild yams of the African forest as potential food resources', in Tropical forests, people, and food: biocultural interactions and applications to development, ed. C Hladik (Paris: UNESCO, 1993), 163-176.

${ }^{178} \mathrm{H}$ Sato, 'The potential of edible wild yams and yam-like plants as a staple food resource in the African tropical rain forest', African Study Monographs, Suppl., 26, (2001): 123-134.

${ }^{179}$ Mercader, "Forest people," 117-124.

${ }^{180} \mathrm{H}$ Yasuoka, 'The variety of forest vegetation in south eastern Cameroon, with special reference to the availability of wild yams for the forest hunter-gatherers', African Study Monographs 30, (2009): 89-119.

${ }^{181}$ M Mirazón Lahr, 'The shaping of human diversity: filters, boundaries and transitions', Philosophical Transactions of the Royal Society B 371, (2016):

20150241.

${ }^{182}$ MacDonald, “Archaeology, language and the peopling of West Africa”, 33-36.

${ }^{183}$ NA Drake et al., 'Ancient watercourses and biogeography of the Sahara explain the peopling of the desert', Proceedings of the National Academy of Sciences U.S.A., 108, (2011): 358-462.

${ }^{184}$ Stojanowski, "Iwo Eleru's place," 80-89. 
